\title{
Capital Accessibility, Gender, and Ethnicity: The Case of Minority Women-owned Firms
}

Leyland M. Lucas

$\bar{M}$

inority women continue to make significant gains in economic activity, particularly as entrepreneurs through the creation of small businesses. Despite this increased role in small business activity and an admirable rate of success, minority women-owned businesses continue to experience problems in acquiring capital. This difficulty, which some have attributed to discriminatory practices, forces a large number of these businesses to rely on governmental support programs for assistance in meeting their capital needs. Building on the idea that things are not as simple as commonly presented, a case is made that access to capital for women-owned businesses is affected by a number of other factors tied to the inability to join important networks.

Small businesses are an essential tenet of the U.S. economy and continue to be created in increasing numbers. According to recent census estimates, small businesses account for more than 35 percent of economic activity and will continue to increase despite changes in the qualifying criteria. Within this broad sector of the economy, even more rapid growth is occurring in the creation and successful operation of small businesses owned and operated by minority women. The number of these firms has been increasing at a faster rate than that of minority males (U.S. Census Bureau 2002), suggesting that minority women-owned businesses are taking on an increasingly important role in the U.S. economy.

Despite continued growth in minority women-owned businesses, attempts by government, private banking, and boutique lenders appear unable to fulfill the need for capital generated by these businesses. As a consequence, many minority women-owned businesses are unable to secure capital for reasons such as unacceptable rates of return, concentration in low-profit industries, and incompatible risk exposure (Greene et al. 2001; Mason and Harrison 1999; Timmons and Bygrave 1997). As a result, stories persist of the challenges that minority women-owned businesses face in accessing capital. Further complicating the issue is the fact that set-aside programs and stereotypical attitudes that view these owners as "too soft" and incapable of making the tough decisions persist are seen as hampering the development of these businesses.

Although these stories persist, there are other valid reasons why minority women-owned businesses have difficulty in accessing capital. The intent of this article is to suggest that, while these attitudes persist, there is a more rational explanation why minority women-owned businesses find access to capital so difficult. We suggest that lending decisions are driven by issues of profitability, return on investment, and the perception that investments are "relatively safe." Such determinations can be made by examining the experience of entrepreneurs, information accessibility, liabilities of newness and size, and management styles. These factors rather than the persistence of prejudice and stereotypical attitudes explain why many minority women-owned businesses find access to capital so difficult.

The next section reviews some of the critical aspects of women and minority-owned businesses. It is followed by arguments and the development of propositions that explain the challenges to capital accessibility among minority womenowned businesses. The article concludes with a discussion of possible implications for these businesses and policy-makers in assessing strategies to increase capital accessibility.

\section{Critical Aspects of Minority Women- owned Businesses}

The essence of entrepreneurial activity is opportunity recognition, timing, and exploitation. Entrepreneurship cannot flourish unless all three of these factors converge. Failure in any one of these areas leads to unfulfilled entrepreneurial goals and objectives. It is the convergence of these three factors that has led to the substantive increase in small business activity.

Having access to capital markets requires knowledge about who has capital available and for what purposes. In reality, however, this knowledge is not perfectly available and minority women entrepreneurs often find themselves at a disadvantage in this respect, because they are not part of the important networks that play a role in the capital markets. To further complicate the issue, minority women entrepreneurs, in their quest for capital, are entering a male-dominated setting and lack the necessary social contacts and skills (Cliff 1998; Greene et al. 2001; Uzzi 1999). The dominance of males in this setting leads to the adoption of specific values and beliefs that appear at odds with those of women. As a consequence, lending to minority women entrepreneurs is seen as a high-risk venture that is unlikely to provide adequate returns.

\section{Conceptual Development}

Success in business often depends more on who knows you 
and what they know about your work than on either what or whom you know. If these entrepreneurs are known to individuals who are part of important networks, then it is easier for information about these entrepreneurs to be shared than in instances where they are not part of these informal networks. Additionally, informal networks often provide significant and valuable information that can either enhance or counter what is already known about an entrepreneur's character.

\section{Experience}

Small businesses are often established by individuals who recognize an opportunity closely related to their current employment. This is particularly the case where these businesses are designed to offer services previously performed by the company but now targeted for outsourcing. To best exploit these opportunities, entrepreneurs must not only recognize that they exist but also have experience that is viewed as critical to the success of their operations (Fiet et al. 2002; Haynes and Haynes 1999; Lerner and Almor 2002). The substance of the argument is that capital exists and lenders are willing to accommodate the needs of entrepreneurs so long as they have the relevant experience and are not pursuing "pies in the skies" dreams (Humphreys and McClung 1981; Schwartz 1976).

Two types of experience are critical to business success and, by extension, access to capital: general and specific (Sigrist 1999). General experience, or business experience, is acquired through the opportunity to work in a large or small corporate body and participate in the making of significant decisions (Humphreys and McClung 1981; Schwartz 1976). Such general experience may be acquired through one's corporate career that may involve opportunities at a single or several corporate entities. Specific experience, or industry experience, is much narrower in scope and deeper in quality because it typically covers exposure to significant decision making within the same industry. Specific experience is idiosyncratic to the particular circumstances surrounding an industry. Through specific experience, an individual gains greater insight into the intricacies of the business cycle as it pertains to a particular industry (Brophy 1989; Coleman 2000; Loscocco and Robinson 1991). These different types of experience are addressed more fully below.

\section{Business Experience}

A critical aspect of business experience is that it provides individuals with access to human capital, which is the stored knowledge and abilities possessed by individuals (Birley et al. 1987). This is achieved through access to occupational experiences that allow individuals to develop skills on several aspects of business that prove to be essential for the creation and operation of successful businesses. Without this human capital, individuals are likely to make critical errors in decisions and these can prove fatal for the business. Anecdotal evidence suggests that this is already a problem among small businesses and contributes to their high failure rates.

Recent studies have found that women now occupy more than 15 percent of senior corporate positions and the number of female chief executives has tripled within the past seven years (Downey 2002). However, these gains among women are not matched by gains among minority women. Though their numbers in undergraduate and graduate fields of study are increasing, minority women in business are highly concentrated in support roles and fields that afford little opportunity for significant senior management experience. The concentration of minority women in these support roles provides them with limited access to the requisite business experience helpful to establishing successful businesses. Although their undergraduate training provided insight into financing, accounting, marketing, and other skills necessary to perform critical business functions, some of the more intricate skills that can only be acquired through exposure to critical decision-making in a "real-world" scenario are not acquired. Minority-women entrepreneurs tend to be well educated. However, they often lack training in critical areas of business that can provide access to important networks (Brush 1992; Lituchy et al. 2004).

The limited business experience has major implications for minority women entrepreneurs to access capital. These difficulties arise because minority women are not part of the critical networks that can provide them with the information needed to gain the business experience (Fabowale 1995; Loscocco and Robinson 1991). For several reasons, minority women find that they are more often involved in tightly knit networks that have few linkages to major players outside of the network. It is access to the players who are outside of the network that are positioned to provide these women with the opportunities to acquire significant business experience and access to capital. In effect, the strong ties established by minority women prevent them from establishing weak ties that create access to funding opportunities. Strong ties provide minority women entrepreneurs with, at best, very narrow business experiences that are often confined to a few areas. Weak ties provide minority women entrepreneurs with broad business experiences that significantly increase their breadth of learning and widen their access to major players who can expose them to multiple funding options (Humphreys and McClung 1981; Schwartz 1976).

Therefore, we suggest that business experience has major consequences for the minority women entrepreneur's efforts to access capital. Because most minorities are concentrated in support roles in businesses, their skill base is limited. A limited skills base means that the human capital developed by these entrepreneurs lacks many of the important skills 
and exposure necessary to operate successful businesses. If these entrepreneurs do not have the requisite knowledge important in making sound business decisions, then lenders are unlikely to provide capital. Lenders want to ensure that individuals entrusted with the task of investing assets have the skills to make good business decisions. Furthermore, concentration in support roles results in minorities developing strong ties that further limit their exposure to critical individuals who might help to develop their skills base. By maintaining strong ties, minorities are unable to create multiple weak ties with individuals who can provide them with access to other skills and who can provide access to capital. From these arguments we draw the following proposition:

\section{Proposition 1:}

Minority women entrepreneurs lacking significant business experience will find it increasingly difficult to access capital.

\section{Industry Experience}

Even when minority women entrepreneurs have significant business experience, the relevance of that experience to their entrepreneurial ventures may create additional problems. Minority women entrepreneurs may be required to have specific industry experience. Significant industry experience suggests that entrepreneurs understand what is important in the industry, know who are the key players, and can better assess trends and opportunities for entrepreneurial activities (Brophy 1989; Coleman 2000; Loscocco and Robinson 1991). Studies have shown that previous experience plays a critical role in the success of small businesses, especially when that experience is within the same industry where these small businesses operate (Brush and Hisrich 1988; Srinivasan, Woo, and Cooper 1994)

Research in this area shows that women owners with access to human capital, particularly in the form of significant senior management experience, and higher levels of education are more likely to access capital than their counterparts without these qualities (Haynes and Haynes 1999; Lerner and Almor 2002). Minority women entrepreneurs with knowledge of the industries in which they operate know what is important to the industry, its trends, and key players. These women, who successfully rose to senior management positions, can use the knowledge and information they acquired to make crucial decisions on which the relative success/failure of their businesses might depend. Their industry experience helps them to better craft their ideas and to provide a well-developed plan of action. With a welldeveloped plan of action, they can determine what sources of capital can be pursued, which prior relationships can facilitate access to capital, and how prior relationships with capital sources can secure better financing terms.
Moreover, minority women entrepreneurs with industry experience not only know the industry but also know some of the "key players." This knowledge helps to reduce information obstacles that limit other entrepreneurs from accessing certain sources of capital. This gives them some legitimacy in the industry among potential financiers who may have dealt with them in the past. If these women have established a good reputation among these potential financiers through their previous contacts, then they will find it much easier to access financing. For instance, access to venture capital is more a function of whom one knows than it is of the viability of the business idea (Brush 1992). From these arguments, we develop the following proposition:

Proposition 2:

Minority women entrepreneurs with significant prior industry experience will likely find it easier to access capital than those without significant industry experience.

\section{Information Accessibility}

Successful entrepreneurs must have access to financial resources.Access to these resources requires that some trusting relationship be developed between the entrepreneur (agent) and the lender (principal). This trusting relationship is particularly important from the perspective of the principal who must be sure that the agent will (1) adhere to the conditions under which the funding has been provided, and (2) has the ability to repay the loan.Trust is essential between the principal and agent because of information asymmetries due to liabilities of newness and smallness (Lant and Mezias 1992). Small businesses, particularly those that are private, do not provide a high quality and quantity of information from which informed decisions by lenders can be made (Berger and Udell 1995; Ennew and Binks 1997). Information essential to the loan decision-making process is unavailable, and faced with this paucity of information, lenders make decisions to deny funding.

In addition to the issues raised previously, an important factor that affects access to capital is information. Prior research has suggested that capital inaccessibility is a result of high search costs both for lenders and entrepreneurs (Wetzel 1987). The gist of the argument is that capital exists, but lenders are frustrated in their efforts to provide capital because entrepreneurs are not hooked into the networks that provide information on capital availability. This lack of information persists despite efforts by governmental and other agencies to provide entrepreneurs with information on capital availability. Consequently, failure to find capital has a discouraging effect whereby entrepreneurs, given the scarcity of resources and the high costs of search, cease to 
pursue potential lending opportunities (Mason and Harrison 2002).

Although absence of information may affect access to capital, of even greater importance is the type of information that can facilitate a successful search. Information acquired must not only provide the entrepreneur with the idea of where capital exists, but also what type of capital exists. In essence, information acquired to facilitate the "meeting" between entrepreneur and capital source must be both general and specific, as they both affect the credit decision-making process (Jensen and Meckling 1992). General information refers to what is widely known not only about the business, but also about the environmental conditions affecting this business (Uzzi and Lancaster 2003). Specific information is idiosyncratic to the particular circumstances surrounding a business.

Although both general and specific information are important to the loan decision-making process, lenders must often deal with incomplete information. Incomplete information results because women-owned businesses, like other small businesses, are often privately held and not subject to the reporting requirements of publicly held institutions (Brush 1992; Hisrich, 1989).

Incomplete information increases ambiguity and the risks associated with a borrower. Prospective lenders find it more difficult to (1) assess the borrower's ability to comply with loan agreements, (2) determine whether the borrower has certain relevant capabilities, and (3) meets lender's requirements (Ennew and Binks 1993). Incomplete information limits the ability of lenders to make an "informed" assessment of the potential borrower.

Lenders can counter these risks in one of three ways. One option is to increase the collateral requirement for borrowers. Increase in collateral requirements, particularly when it involves personal assets, is seen as an intrinsic motivator to success. The borrower knows that failure to meet expectations will result in a loss of the collateral, which may include very prized personal assets. Several studies have found that pledging collateral often facilitates borrowing among small businesses (Ang et al. 1995; Broome 1990). A second option is to increase the rate of interest. Charging higher rates of interest not only reflects risk levels, but also helps to compensate for information asymmetry and exposure of lenders to greater risk (Petersen and Rajan 1994). A third option available to lenders is to pursue lending relationships primarily with long-term customers. With long-term relationships, lenders have the opportunity to observe performance, financial and otherwise, and develop additional information that would not necessarily be available. Long-term relationships provide additional information, improve the quality of the relationship between the lender and borrower, and increase the likelihood that the borrower will adhere to the conditions stipulated in the loan agreement.

However, there are problems with all three of these options. With respect to pledging increased collateral, financial institutions are in the business of lending money and not in the business of managing and liquidating assets. Performing these functions places additional burdens on lenders that can be eliminated through more selective lending. Although lenders can also compensate for risk by charging higher interest rates, there is a point beyond which managing such loans is not feasible. Beyond a specific threshold, the benefits from maintaining high rate/high risk loans are far outweighed by their costs. Building long-term relationships is not an option for many women-owned businesses because most are relatively new. In addition, recent decisions within the banking industry to centralize the loan decision-making process reduce the value of building long-term relationships, especially when many of those relationships would have been built with branch personnel no longer involved in the loan decision-making process (Uzzi and Lancaster 2003). The challenges associated with each of these options not only increase the risk potential of lending to these businesses, but also the cost of lending for both parties. Minority women businessowners are forced to borrow at higher interest rates and lenders incur additional monitoring costs. From these arguments, one can draw the following proposition:

\section{Proposition 3: \\ Information accessibility will have a significant influence on access to capital for minority women entrepreneurs.}

\section{Liability of Newness}

The age of a business affects its performance, and its ability to survive. New businesses lack the broad bases of influence, endorsement, and stable relationships with important constituents. New businesses suffer from a liability of newness and this translates into a greater likelihood of failure (Baum and Oliver 1991; Carroll 1983; Stinchcombe 1965). Newer businesses are more vulnerable to environmental shocks because they are still in the process of developing an understanding of how the industry works (Lant and Mezias 1992). In addition, these new businesses have not yet established the important linkages that may affect their awareness of environmental forces, industry trends, and emerging opportunities. Older small businesses have survived the liability of newness, while younger ones are yet to show that they have survived this liability (Lant and Mezias 1992). By surviving the liability of newness, women-owned small businesses have demonstrated that they have the ability to be competitive, rather than remain stagnant and die. 
Older minority women-owned small businesses that have survived the liability of newness may be better positioned to access capital. With older businesses, more information is available about their performance. By surviving, these businesses have demonstrated the ability to "do things right." Moreover, as these businesses age, management is better able to delegate responsibility and concentrate on strategic issues. Roles are more clearly defined and higher levels of trust exist. As small businesses grow older more information about them becomes available. Although there is a tendency to keep information private, some information does seep into the public domain permitting lenders to make more informed decisions regarding loan applications than would be the case for new small businesses. From these arguments, one can draw the following proposition:

\section{Proposition 4:}

Older minority women-owned small businesses will find it easier to access capital than their younger counterparts.

\section{Liability of Smallness}

The decision to either grow or remain small is a strategic one that every entrepreneur must consider. Opportunities to grow may exist, but decisions against growth may be made because the businessowners are risk-averse and this may continue even as wealth increases (Brown and Segal 1989; Jianakoplos and Bernasek 1998; Olsen and Currie 1992). By maintaining a relatively small operation, minority women maintain their risk-aversion and limit their need for capital. Small firms require less need for external capital particularly if they do not operate in capital-intensive industries. By maintaining relatively small businesses, minority women entrepreneurs can rely on their personal savings and retained earnings for funding of expansion. Decisions regarding growth have implications for resource endowment, capital requirements, and capital structure (Greene and Brown 1997). It also raises issues regarding control, a subject that may be critical to minority women entrepreneurs. As minority women entrepreneurs increase their debt-equity ratio, the degree of control over their operations decreases. The actions they undertake are increasingly subject to the oversight of external parties more concerned with ensuring loan repayment than in the long-term survival of the business. By opting to remain small, these businesses are constrained in achieving their full potential. Constraints on growth may subsequently harm these minority women-owned businesses because their client base is less diversified than would otherwise be the case. This lack of diversification further exposes these small businesses to fluctuations of the business cycle.

The emphasis on maintaining small businesses translates into what had been termed "the liability of smallness."
Small businesses have a greater likelihood of either dying or failing to access much needed capital because they can be effectively screened out of the population without significantly affecting the level of competition. This is referred to as "the impact of niche width" (Freeman et al. 1983; Levins 1968; Loscocco and Robinson 1991). Niche width is defined as a population's tolerance for factors that inhibit growth. The greater the tolerance for growth inhibitors, the broader is the perceived niche width.

One important characteristic of niche width is spatial distribution, which is the extent of variety. When patterns are difficult to identify, spatial distribution is said to be high, otherwise it is low. The existence of significant numbers of small businesses in the service sector suggests that there are large groups of homogeneous businesses and a lack of spatial distribution. The existence of large groups of homogeneous small businesses increases the possibility for low profit margins and allows lenders to be more selective. The more marginally profitable small businesses have a higher propensity for failure because they operate close to the margin and find it more difficult to attract resources, including capital. As a result, lenders are more selective in their loan decisions. Given the abundance of small businesses, lenders can then pay less attention to the marginally profitable businesses and focus on lending to the more profitable ones.

Thus, issues of control and spatial distribution may result in minority women entrepreneurs operating small businesses that lenders may be less willing to fund. Several of these businesses operate at or close to the margins and this translates into a greater likelihood of failure. The closer a small business is to the margins, the lower is the capital available to absorb cyclical fluctuations in economic activity. From a lender's perspective, low profit margins also decrease the potential for debt repayment. With an overabundance of small businesses, lenders can be more selective in their loan decision-making choosing to focus on more profitable businesses rather than expose themselves to greater risk of loan default. From these arguments, one can draw the following proposition:

\section{Proposition 5:}

A preference for maintaining small businesses by minority women entrepreneurs will limit their ability to access capital.

\section{Conclusions}

Small businesses continue to act as an important source of economic growth and play a critical role in the U.S. economy. Coupled with this role has been a significant growth in the number of minority women-owned small businesses. To support this growth, several programs have been designed to 
further promote their chances for success. Despite these efforts, problems still persist for minority women businessowners. One problem many of these businessowners face is accessing capital. Though some have suggested that inaccessibility to capital is a result of discriminatory policies, this article makes the argument that inaccessibility occurs because minority women entrepreneurs are often absent from important networks. These important networks help in skill development, provide entrepreneurs with access to critical information, and help to facilitate the views formed about their abilities to operate small businesses successfully.

While issues of discrimination may prevail, there are other reasons why women entrepreneurs find it difficult to access capital. Lack of access to capital can be explained by inexperience, information inaccessibility, and liabilities of newness and size-all of which are in some way related to the need to become part of the important networks. Capital will be provided to businesses that have demonstrated the ability to be highly profitable and successful. The objective of lending is to secure an adequate return on investment. If businessowners show that their businesses are viable, then funds will be made available. Failure to demonstrate viability of a business is not a function of discrimination but due to certain idiosyn- cratic conditions operating within small businesses and among small businessowners.

Minority women businessowners must take a different approach to accessing capital rather than the ones currently used. Faced with these idiosyncratic conditions in the small business segment, these businessowners must find ways to counter the perceived gaps in their abilities. For instance, focusing on relationship banking may help in the long run but is of little value in the short term. Therefore, minority women businessowners might consider finding ways to increase information availability.

Finally, although minority women businessowners need to adopt new approaches in accessing capital, generating behavioral change is not easily achieved. It is a process that can only be pursued over time and the results of such change may be difficult to discern. Small businesses operate in changing environments and, as these businessowners enact change, old challenges will disappear and new ones will emerge. Therefore, minority women businessowners must find ways to either anticipate new challenges or counter them. The fact that women businesses continue to grow despite these challenges to capital access may show some hope for the future.

\section{References}

Ang, J. S. et al. 1995. Evidence on the lack of separation between business and personal risks among small businesses.Journal of Small Business Finance 4: 197-210.

Baum, J.A., and C. Oliver. 1991. Institutional linkages and organizational mortality. Administrative Science Quarterly 36: 187-218.

Berger,A.N., and G. F. Udell. 1995. Relationship lending and lines of credit in small business finance. Journal of Business 68: 351-382.

Birley, S., et al. 1987. Do women entrepreneurs require different training? American Journal of Small Business 12: $27-35$.

Broome, J. 1990.A loan at last? Nation's Business 82: 40-44.

Brophy, D. J. 1989. Financing women-owned entrepreneurial firms. In O. Hagan, C. Rivcum, and D. Sexton, eds., Women-owned businesses. New York: Praeger.

Brown, S.A., and P. Segal. 1989. Female entrepreneurs in profile. Canadian Banker (July-August): 32-34.

Brush, C. 1992. Research on women business owners: Past trends, a new perspective and future directions. Entrepreneurship Theory and Practice 16:5-30.

Brush, C., and R. D. Hisrich. 1988. The women entrepreneur: Strategic origins-impact on growth. Frontiers of Entrepreneurship Research. Babson Park, MA: Center for Entrepreneurial Research, Babson College.

Carroll, G. R. 1983. A stochastic model of organizational mortality: Review and reanalysis. Social Science Research 12: 303-329.

Cliff, J. 1998. Does one size fit all? Exploring the relationship between attitudes towards growth, gender, and business size. Journal of Business Venturing 13: 523-542.

Coleman, S. 2000. Access to capital and terms of credit: A comparison of men- and women-owned small businesses. Journal of Small Business Management 38: 37-52.

Ennew, C., and M. Binks. 1993. Financing entrepreneurship in recession: Does the banking relationship constrain performance? In N. C. Churchill et al., eds., Frontiers of Entrepreneurship Research. Babson Park, MA: Center for Entrepreneurial Studies Babson College, 481-495. 
Ennew, C., and M. Binks. 1997. Information asymmetries, the banking relationship and the implications for growth. In N. C. Churchill et al., eds., Frontiers of Entrepreneurship Research. Babson Park, MA: Center for Entrepreneurial Research, Babson College.

Fabowale, L. et al. 1995. Gender, structural factors, and credit terms between Canadian small businesses and financial institutions. Entrepreneurship, Theory \& Practice 19: 41-67.

Fiet, J., et al. 2002. Still searching (systematically) for entrepreneurial discoveries. Small Business Economics 25: $489-515$.

Freeman, J. H., et al. 1983. The liability of newness:Age dependence in organizational death rates. American Sociological Review 88: 1116-1145.

Greene, P., and T. Brown. 1997. Resource needs and the dynamic capitalism typology.Journal of Business Venturing 12: 161-173.

Greene, P., et al. 2001. Patterns of venture capital funding: Is gender a factor? Venture Capital 3: 63-83.

Haynes, G. W., and D. C. Haynes. 1999. The debt structure of small businesses owned by women in 1987 and 1993.Journal of Small Business Management 37: 1-18.

Hisrich, R. D. 1989. Women entrepreneurs: Problems and prescriptions for success in the future. In O. Hagan, C. Rivchun, and D. Sexton, eds., Women business entrepreneurs. New York: Praeger.

Humphreys, M.A., and H. McClung. 1981. Women entrepreneurs in Oklahoma. Review of Regional Economics and Business 6, 2: 13-20.

Jensen, M. C., and W. H. Meckling. 1976. Theory of the firm: Managerial behavior, agency costs and ownership structure. Journal of Financial Economics 3: 305-360.

Jensen, M. C., and W. H. Meckling. 1992. Specific and general knowledge and organizational structure. In L. Werin and H. Wijkander, eds., Contract Economics. Cambridge, MA: Blackwell Publishers.

Jianakoplos, N.A., and A. Bernasek. 1998. Are women more risk averse? Economic Inquiry 36: 620-630.

Lant,T. K., and S. J. Mezias. 1992.An organizational learning model of convergence and reorientation. Organization Science 3: 47-71.

Lerner, M., and T.Almor. 2002. Relationship between strategic capabilities and the performance of women-owned small ventures.Journal of Small Business Management 40: 109-125.

Levins, R. 1968. Evolution in changing environments. Princeton, NJ: Princeton University Press.

Lituchy, T., and M. Reavley. 2004. Women entrepreneurs: A comparison of international small business owners in Poland and the Czech Republic.Journal of International Entrepreneurship 2: 61-87.

Loscocco, K.A., and J. Robinson. 1991. Barriers to women's small business success in the United States. Gender E Society 5: 511-532.

Mason, C., and R. Harrison. 2002. Barriers to investment in the informal venture capital sector. Entrepreneurship E Regional Development 14: 271-287.

Mason, C., and R. Harrison. 1999. Venture capital: rationale, aims, and scope. Venture Capital 1: 1-46.

Olsen, S., and H. Currie. 1992. Female entrepreneurs: Personal value systems and business strategies in a male-dominated industry.Journal of Small Business Management 30: 49-57.

Petersen, M., and R. Rajan. 1994. The benefits of lending relationships: Evidence from small business data. Journal of Finance 49: 3-38.

Schwartz, E. B. 1976. Entrepreneurship:A new female frontier. Journal of Contemporary Business 5: $47-76$.

Sigrist, B. 1999. Entrepreneurial opportunity recognition. Presented at the Annual UIC/AMA symposium at Marketing/Entrepreneurship Interface. Sofia-Antipolis, France.

Srinivasan, R., C. Woo, and A. Cooper. 1994. Performance determinants for male and female entrepreneurs. Frontiers of Entrepreneurship Research. Babson Park, MA: Center for Entrepreneurial Research, Babson College.

Stinchcombe, A. L. 1965. Social structure in organizations. In J.G. March, ed., Handbook of organizations. Chicago: Rand McNally, 153-193. 
Timmons, J.A., and W. D. Bygrave. 1997. Venture capital: Reflections and projections. In D.L. Sexton and R. Smilor, eds., Entrepreneurship 2000. Chicago: Upstart Publishing, 29-46.

U.S. Census Bureau. 2002. Survey of women-owned firms. Washington, DC: U.S. Department of Commerce, Economics and Statistics Administration.

Uzzi, B. 1999. Embeddedness in the making of financial capital: How social relations and networks benefit firms seeking financing. American Sociological Review 64: 481-505.

Uzzi, B., and R. Lancaster. 2003. Relational embeddedness and learning:The case of bank loan managers and their clients. Management Science 49: 383-399.

Wetzel Jr., W. E. 1987. The informal venture capital market: Aspects of scale and market efficiency.Journal of Business Venturing 2: 299-314.

\section{About the Author}

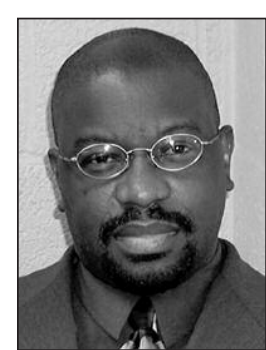

LEYLAND M. LuCAS (llucas@moac.morgan.edu) is an associate professor of management in the Earl Graves School of Business \& Management at Morgan State University. He received his Ph.D. in organization management from Rutgers University. Dr. Lucas has published papers in Entrepreneurship Theory E Practice, International Journal of Technology Management, Journal of Knowledge Management, The Learning Organization, and Journal of Applied Management E Entrepreneurship. His research interests include organizational search, knowledge management, opportunity recognition, minority and women-based entrepreneurship, and innercity entrepreneurship. 